\title{
Isolation and Purification of High Efficiency L-asparaginase by Quantitative Preparative Continuous-elution SDS PAGE Electrophoresis
}

\author{
Senthil Kumar $\mathbf{M}^{1 *}$ and Selvam $\mathbf{K}^{2}$ \\ ${ }^{1}$ Dept of Biotechnology, Bharathiar university, Coimbatore, Tamilnadu, India \\ ${ }^{2}$ Dept of Biotechnology,Dr.NGP college of Arts and Science, Coimbatore, Tamilnadu,India
}

\begin{abstract}
An Unique extracelluar glutaminase free L-asparaginase from novel marine Actinomycetes was isolated to perceptible homogeneity in agro industrial wastes. Quantitative Preparative Continuous-Elution SDS PAGE Electrophoresis is a high-resolution method for the preparative isolation of L-Asparaginase in biological samples. The enzyme was purified 248.68 -fold and showed a final specific activity of $5035.28 \mathrm{IU} / \mathrm{mg}$ with an $80.71 \%$ yield . The homotetramer enzyme has a molecular mass of $133.25 \mathrm{kDa}$ and an isoelectric point of approximately 5.4.Kinetic parameters, $\mathrm{Km}$ and Vmax of purified L-asparaginase from Streptomyces radiopugnans MS1 were found to be $0.0598,3.5478 \mathrm{IU} \mu \mathrm{g}^{-1}$ respectively. The de novo sequencing strategy presented here provides a rapid and reliable means to identify proteins in Streptomyces radiopugnans MS1. The purified L-asparaginase has no glutaminase activity, which can diminish the leeway of side effects during the itinerary of anti-malignancy therapy.
\end{abstract}

Keywords: Streptomyces radiopugnans MS1; De novo sequencing; L-Asparaginase; Anti-malignancy therapy

\section{Introduction}

$\mathrm{L}$-asparaginase is used in the treatment of malignancies of the multiorgans [1]. The use of L-asparaginase in anti-cancer therapy is based on its ability to catalyze the conversion of L-Asparagine to L-Aspartate and ammonia in human body fluid. On the whole lymphoblasts are unable to produce endogenous L-asparagine, starvation for this amino acid leads to death of these cells [2]. Enormous numbers of researches have been accomplished on the biosynthesis of this therapeutically important L-Asparaginase, since Mashburn and Wriston demonstrated anti tumor activity [3].

The FDA and WHO organizations have approved L-asparaginase for the successful treatment of Acute Lymphoblastic Leukemia (ALL) and Lymphsarcoma. Proportional examinations of preparations of $E$. coli, L-asparaginase produced in the USSR, Germany (Crasntin) and Japan (Leumase) were made [4] and it revealed that clinically USSR preparation was superior to that made in Japan.

Recently, Gupta et al. [5] reported that marine actinomycetes have been shown to be a good source for L-Asparaginase because of extreme adaptation with in marine environment.

Literatures information showed that the enzyme's biochemical and kinetic properties vary with the hereditary nature of the microbial strain used [6]. For example, Erwinia L-asparaginase revealed less anaphylactic reactions evaluated to the E. coli enzyme. Though, Erwinia asparaginase had a shorter half-life than E. coli [7]. In addition, contamination with glutaminase is one of the causes of toxicity $[8,9]$. Therefore, there is a need to find novel sources of the enzyme that are free of glutaminase and are serologically diverse but have comparable therapeutic effects. This may necessitate the screening of Marine soil samples from various sources for isolation of potential Actinomycetes, which have the aptitude to produce the desired L-Aspararginase.

The processing of agro-industrial raw materials such as Tapioca produces the large amount of waste, whose accretion leads to environmental pollution. Due to the high amounts of starch or reducing sugar, those wastes has been recognized as an appropriate feedstock for industrial fermentations such as volatile compounds [10].

The production of L-Asparaginase was inclined by the different kind of physical and chemical environment. An indulgent of the mechanisms of stimulation of enzyme in micro-organisms is significant for designing ways to attain maximum yield. These incorporate manipulation of the medium constituents and optimization of the physicochemical parameters, which can influence enzyme excrete and cell mass development. Biosynthesis of L-asparaginase by Actinomycetes was commenced to facilitate discover the optimal cultural conditions to get maximum yield.

Purification and analytical separation of L-Asparaginase have been carried out by using different chromatographic methods, e.g. ion exchange chromatography with DEAE cellulose and recently Sephadex G-200 chromatography and also by different electrophoretic methods. Many of the above separation methods are either uneconomical or too time consuming to be used routinely for large scale purification. We report here a High yield method which can be used for both preparative and analytical scale purification of L-Asparaginase with SDS PAGE by using continuous elution electrophoresis.

Contemporary proteomics entails prompt and confident protein identification of proteins of interest. The presented method consists primarily of de novo sequencing of underivatived peptides using the MALDITOF-TOF, compared to various derivative strategies used

${ }^{*}$ Corresponding author: M Senthil Kumar, Dept of Biotechnology, Bharathiar university, Coimbatore,Tamilnadu, India, Tel: +91 9884813502; E-mail: pearlsen78@gmail.com

Received October 01, 2011; Accepted November 15, 2011; Published November 19, 2011

Citation: Senthil Kumar M, Selvam K (2011) Isolation and Purification of High Efficiency L-asparaginase by Quantitative Preparative Continuous-elution SDS PAGE Electrophoresis. J Microbial Biochem Technol 3: 073-083. doi:10.4172/19485948.1000055

Copyright: (C) 2011 Senthil Kumar M, et al. This is an open-access article distributed under the terms of the Creative Commons Attribution License, which permits unrestricted use, distribution, and reproduction in any medium, provided the original author and source are credited 
recently for various de novo studies. The generated sequences were used to perform homology searches to characterize the protein identification. The current study validates a robust method to confidently characterize proteins from sequence database of Streptomyces Sps.

\section{Materials and Methods}

\section{Screening of L-asparaginase production strain}

Marine soil samples were collected from from Bay of Bengal, Mahabalipuram,India.Soil samples was treated with tapioca effluent for enrichment and incubated at an ambient temperature for about a week at 200rpm. The diluted samples were screened for Lasparaginase production by rapid plate assay procedure [11,12]. Among the 29 strains tested by the plate assay and broth studies, the colonies showing wider zone with pink color were used for further study.

\section{Isolation and identification of actinomycetes}

The isolates were identified by various parameters such as Colony morphology, spore arrangement, Staining, physiological, Biochemical reactions [13] and 16S rRNA gene amplification and DNA sequencing $[14,15]$.

\section{Inoculums development}

The strain of Actinomycetes was inoculated in minimal broth incubated at $28{ }^{\circ} \mathrm{C}$ for $24-48 \mathrm{~h}$ was used for inoculums development. $5 \%$ of the active culture from the medium was used to inoculate 250 $\mathrm{ml}$ Erlenmeyer flask containing $50 \mathrm{ml}$ of the culture medium: \{fructose $(1.0 \mathrm{~g} / \mathrm{l}) ; \mathrm{K}_{2} \mathrm{HPO}_{4}(1.0 \mathrm{~g} / \mathrm{l})$; Yeast extract $(5.0 \mathrm{~g} / \mathrm{l})$; tryptone $\left.(5.0 \mathrm{~g} / \mathrm{l})\right\}$ and grown at $28{ }^{\circ} \mathrm{C}$ for 7 days and $250 \mathrm{rpm} .1 \%$ of the culture medium used further for production and media optimization studies.

\section{Growth of Actinomycetes on different media and enzyme activity}

The culture strain was grown in triplicate for 7 days at $28^{\circ} \mathrm{C}$ on the following media containing $1 \%$ of $\mathrm{L}$-asparagine:

1. Fermentation medium F1; Czapekdox medium (g/l) Solution A: L-asparagine,1.0; Sodium Nitrate 4.0; Potassium Chloride 1.0; $\mathrm{MgSO}_{4} .7 \mathrm{H}_{2} \mathrm{O}, 0.052 ; \mathrm{FeSO}_{4} .7 \mathrm{H}_{2} \mathrm{O}, 0.02$; dissolved in distilled water and stored in refrigerator. Solution $\mathrm{B}: \mathrm{K}_{2} \mathrm{HPO}_{4} 2.0$; dissolved in distilled water and stored in refrigerator. Solution C: $1 \mathrm{gm}$ of $\mathrm{ZnSO}_{4} .7 \mathrm{H}_{2} \mathrm{O}$ dissolved in distilled water. Solution D: 0.5 gm of $\mathrm{CuSO}_{4}$. $\mathrm{H}_{2} \mathrm{O}$; dissolved in distilled water. For one litre of Czapek-Dox medium; contains $50 \mathrm{~mL}$ of solution $\mathrm{A}, 50$ $\mathrm{mL}$ of solution $\mathrm{B}, 1 \mathrm{~mL}$ of solution $\mathrm{C}$ and solution $\mathrm{D}, 900 \mathrm{~mL}$ of distilled water, 30 gm of glucose. $\mathrm{pH} 6.8$

2. Fermentation medium F2 ;Tapioca effluent (75\% v/v),Natural sea water $(25 \% \mathrm{v} / \mathrm{v}) \mathrm{pH} 7.2 \sim 7.4$

3. Fermentation medium F3 containing (g/l) casein hydrolysate (3.0\%), corn steep liquor (3.5\%) pH 6.8

4. Fermentation medium F4 containing $(\mathrm{g} / \mathrm{l})$, yeast extract 10; different amino acids $0.01 \mathrm{M} ; \mathrm{pH} 6.8$

5. Fermentation medium F5 containing sodium formate (100 $\mathrm{mM})$; sodium fumarate (100 mM); Yeast extract $0.5 \%$; $\mathrm{pH} .6 .8$

\section{Optimization of culture conditions for L-asparaginase production}

The culture conditions like $\mathrm{pH}$, temperature, incubation period and different carbon and nitrogen sources were optimized for maximum enzyme production using standard media [Tapioca effluent $(75 \%$ $\mathrm{v} / \mathrm{v})$,Natural sea water $(25 \% \mathrm{v} / \mathrm{v})$, Corn steep liquor $(2 \% \mathrm{w} / \mathrm{v})$,Peptone $(1 \% \mathrm{w} / \mathrm{v})$,yeast extract $(1.5 \% \mathrm{w} / \mathrm{v}), \mathrm{KH}_{2} \mathrm{PO}_{4}(0.1 \% \mathrm{w} / \mathrm{v}), \mathrm{Mgso}_{4}(0.5 \%$ $\left.\mathrm{w} / \mathrm{v}), \mathrm{CaCO}_{3}(0.4 \% \mathrm{w} / \mathrm{v}) \mathrm{pH} 7.2 \sim 7.8\right]$ in $250 \mathrm{ml}$ Erlenmeyer flask and incubated at $30^{\circ} \mathrm{C}$ for $24 \mathrm{~h}$. The L-asparaginase production was carried out in $500 \mathrm{ml}$ Erlenmeyer flask containing $100 \mathrm{ml}$ sterile media as mentioned above inoculated with $2 \%$ inoculums and maintained at $30^{\circ} \mathrm{C}$ for 7 days on shaker incubator $(250 \mathrm{rpm})$ for enzyme production. The samples were collected every $24 \mathrm{hrs}$ and assayed for L-asparaginase activity at optimum enzyme production the culture medium was harvested and centrifuged at 10,000 rpm for $30 \mathrm{~min}$ to obtain the cell pellets, used as enzyme source.

\section{Enzyme purification and quantification}

All purification steps were carried out at $4^{\circ} \mathrm{C}$. All chromatographic runs were monitored for protein at $280 \mathrm{~nm}$.

Asparaginase activity assay and protein: L-asparaginase activity was assayed by a modified method of Mashburn and Wriston [16]. A $0.1 \mathrm{ml}$ sample of cell suspension or purified enzyme solution, $0.9 \mathrm{ml}$ of $0.1 \mathrm{M}$ sodium borate buffer $(0.1 \mathrm{M}, \mathrm{pH} 8.5)$ and $1 \mathrm{ml}$ L-1 asparagine $(0.04$ M) solution were combined and incubated for $10 \mathrm{~min}$ at $37^{\circ} \mathrm{C}$. The reaction was stopped by the addition of $0.5 \mathrm{ml}$ of $15 \% \mathrm{wt} / \mathrm{vol}$ trichloro acetic acid. The reaction contents were centrifuged at $10,000 \mathrm{rpm}$ at 20 $\mathrm{min}$. The supernatant was collected and $0.2 \mathrm{ml}$ supernatant was diluted to $8 \mathrm{ml}$ with distilled water. The resulting mixture was treated with 1.0 $\mathrm{ml}$ of Nessler's reagent and $1.0 \mathrm{ml}$ of $2.0 \mathrm{M} \mathrm{NaOH}$. The color reaction was allowed to proceed for $15 \mathrm{~min}$ before the absorbance at $500 \mathrm{~nm}$ was determined (Xmark, Bio-Rad, Hercules, CA). The absorbance was then compared with a standard curve prepared from solutions of ammonium sulfate as the ammonia source. One international unit of L-asparaginase is the amount of Enzyme which liberates $1 \mu$ mole of ammonia in $1 \mathrm{~min}$ at $37^{\circ} \mathrm{C}$.

Protein concentration was determined at $25^{\circ} \mathrm{C}$ by the method of Bradford [17] using bovine serum albumin (fraction V) as standard.

Ammonium sulfate precipitation: Finely powdered ammonium sulfate was added to the clear supernatant obtained after Centrifugation and incubated overnight. Maximum L-asparaginase activity was observed with the fraction precipitated at $60-80 \%$ saturation. The precipitate was collected by centrifugation at $10000 \mathrm{rpm}$ for $30 \mathrm{~min}$ and dissolved in a minimal amount of $50 \mathrm{mM}$ Tris- $\mathrm{HCl}$ buffer $(\mathrm{pH}$ 8.6) and dialyzed against the same buffer for 24 hours.

DEAE cellulose chromatography: The dialyzed ammonium sulphate sample was loaded on diethylaminoethyl (DEAE) cellulose column. Before loading the sample, the column was pre-equilibrated with $50 \mathrm{mM}$ Tris- $\mathrm{HCl}(\mathrm{pH} \mathrm{9.6)}$ at a flow rate of $1 \mathrm{ml} \mathrm{min}$. The column was washed with two column volume of the above buffer and the adsorbed protein was eluted using a linear gradient of $\mathrm{KCl}$ $(0-200 \mathrm{mM})$ in $50 \mathrm{mM}$ Tris- $\mathrm{HCl}(\mathrm{pH}$ 8.6).L-Asparaginase activity containing fractions obtained after the ion exchange chromatography were pooled, dialyzed with Tris- $\mathrm{HCl}(50 \mathrm{mM}$ and $\mathrm{pH}$ 8.6) and concentrated with bench top lyophilizer (Model Alpha1-4, Christ Gefriertrocknungsanlagen $\mathrm{GmbH}$, Germany) operated at $-55^{\circ} \mathrm{C}$ and $2.1 \mathrm{~Pa}$ for 24 hours.

Sephadex G-200 chromatography: The dialyzed and lyophilized sample from the above step was loaded on pre-equilibrated Sephadex 
G-200 column with $50 \mathrm{mM}$ Tris-HCl buffer $\mathrm{pH}$ 8.6. The protein elution was done with the same buffer at a flow rate of $0.2 \mathrm{ml} \mathrm{min-1.} \mathrm{The} \mathrm{active}$ fractions were pooled, concentrated with lyophilizer and dialyzed against the Tris- $\mathrm{HCl}$ buffer $(50 \mathrm{mM}, \mathrm{pH}$ 8.6). This concentrated fraction was stored at $-20^{\circ} \mathrm{C}$.

Quantitative preparative continuous- Elution SDS polyacrylamide gel electrophoresis: Twenty milligrams of lyophilized protein were solubilized in $3 \mathrm{ml}$ of solubilization sample buffer $(0.06 \mathrm{M}$ Tris$\mathrm{HCl}, \mathrm{pH} 6.8,2 \%$ SDS, 5\% beta-mercapto-ethanol,10\% glycerol and $0.025 \%$ bromophenol blue) and the mixture was incubated at $95^{\circ} \mathrm{C}$ for 4 min. The total sample volume was applied to the top of the stacking gel and the separation was conducted in a "Prep Cell" system, model 491 (Bio-Rad, Hercules, CA) according to the manufacturer's instructions with the following specifications of gel tube size $37 \mathrm{~mm}$ : a $7 \%$ acrylamide separating gel (10 cm in height) and a $4 \%$ acrylamide stacking gel (1.5 cm in height) were used. Running buffer was Tris-glycine-SDS (25-192 mM-0.1\%, pH 8.3) and the elution buffer was Tris-glycine (25$192 \mathrm{mM})$. The run was conducted at $12 \mathrm{~W}$ constant power $(55 \mathrm{~mA} / 200-$ 400 volts) for a total of $10 \mathrm{~h}$. After elution of bromphenol blue tracking dye, fractions were collected at a rate of $1.0 \mathrm{ml} / \mathrm{min}$. The polypeptide composition of every tenth fraction was analyzed by $12-14 \%$ SDSPAGE . The fractions were lyophilized to give dry, salt-free material, and were further purified by preparative isoelectric focusing (IEF).

Molecular mass determination: The native molecular weight of the purified enzyme was determined by Native PAGE method. Native PAGE of the purified L-asparaginase was performed on $7.5 \%$ polyacrylamide gel in glycine buffer at $5 \pm 1^{\circ} \mathrm{C}$ as described by Gallagher [18]. SDS-PAGE was performed by the modified method of Laemmli [19] with a $12.5 \%$ separating acrylamide gel $(\mathrm{pH} 8.8)$ and a $5 \%$ stacking gel ( $\mathrm{pH}$ 6.8) containing $0.1 \%$ SDS. Electrophoresis was performed using Tris-glycine buffer $(\mathrm{pH} 8.3)$ at $120 \mathrm{~V}$ for $3 \mathrm{~h}$ at room temperature and the proteins in the gel were stained with Coomassie Brilliant Blue R-250. Approximate subunit molecular weight and intact molecular weight of L-asparaginase was determined using standard molecular weight markers in SDS-PAGE and Native PAGE, respectively

Estimation of $\mathrm{pI}$ and 2D analysis: The isoelectric focusing polyacrylamide gel electrophoresis (IEF-PAGE) was performed in a PROTEAN IEF (Bio-Rad, Hercules, CA) System using ReadyStrip ${ }^{\text {Tw }}$ IPG strips(Bio-Rad) of $\mathrm{pH}$ range 4-7. Approximately $169 \mu \mathrm{g}$ of purified protein was applied to the gel and focused at $14,000 \mathrm{~V}$-hr for a period of 7-8 h. Protein band was visualized with Coomassie Brilliant Blue R-250 stain [20] and evaluate with the associated Quantity one 4.6.5.software (Bio-Rad, Hercules, CA).

Two-dimensional PAGE (2D-PAGE) was performed using a Protean IEF cell with ReadyStrip IPG Strips pH range 4-7 (BioRad, Hercules, CA). The 2-D-gel images were digitized using a GS710 densitometer (Bio-Rad, Hercules, CA) and analyzed with the accompanying PD Quest 8.0.1 software (Bio-Rad, Hercules, CA).

Protein spot digestion: Individual protein spots from the 2-D gels were excised with $1.5 \mathrm{~mm}$ diameter gel cutter (EXQuest spot cutter, Bio-Rad, Hercules, CA) [21]. The gel spots were washed for 20 min, twice in $100 \mu \mathrm{l}$ of solution of $50 \mathrm{mM}$ ammonium bicarbonate, $50 \%$ methanol $(\mathrm{v} / \mathrm{v})$ in distilled water and once in $75 \%$ acetonitrile in distilled water for $30 \mathrm{~min}$ or until the gel plugs turned opaque. Twenty micrograms of lyophilized trypsin $(883$ pmol; Promega, Madison,
WI) was reconstituted in $1 \mathrm{ml}$ of $20 \mathrm{mM}$ ammonium bicarbonate and incubated for $15 \mathrm{~min}$ at $37^{\circ} \mathrm{C}$. The gel fragments were dried by vacuum centrifugation and then incubated overnight with $10 \mu \mathrm{l}(200 \mathrm{ng})$ of trypsin at $37^{\circ} \mathrm{C}$. The supernatant from trypsin digest was transferred to a low retention 96-well plate. Peptides from the gel pieces were sequentially extracted twice in $100 \mu \mathrm{l}$ of extraction buffer [50\% (v/v) acetonitrile, $0.1 \%(\mathrm{v} / \mathrm{v})$ trifluoroacetic acid (TFA) in distilled water (DW)]. The original tryptic supernatant and the supernatants from two sequential extractions were combined and dried in a vacuum centrifuge. The dried peptides from each gel plug were dissolved in 5 $\mu \mathrm{l}$ of $50 \%(\mathrm{v} / \mathrm{v})$ acetonitrile, $0.1 \%$ trifluoroacetic acid in distilled water and $0.5 \mu \mathrm{l}$ deposited on the stainless-steel MALDI target plate. After drying, the spot residue was mixed with $0.5 \mu \mathrm{l}$ of $5 \mathrm{mg} / \mathrm{ml}$ of $\alpha$-cyano-4hydroxy-cinnamic acid (CHCA; Sigma-Aldrich, St. Louis, MO) in 50\% (v/v) acetonitrile, $0.1 \%$ trifluoroacetic acid in distilled water [22].

Mass spectrometry analyses were performed using the Applied Biosystems 4700 Proteomics Analyzer (MALDITOF-TOF; Foster City, CA) in reflector mode for positive ion detection.

The PEAKS Studio 5.3 (Bioinformatics Solutions, Waterloo, Ontario, Canada) de novo sequencing software was used for automated de novo sequencing followed by manual confirmation of most sequences generated. The algorithm used for determining the probability based scoring with a given mass spectrum is described in detail by $\mathrm{Ma} \mathrm{B}$ et al. [23]. Protein identification was confirmed by checking the protein mass and pI accuracy [24].

Determination of amino acid composition: This was carried out on the purified enzyme using a Beckman Amino Acid Analyzer (Model 119 GL), according to the method of Speckman et al. [25].

\section{Kinetic properties of the purified L-asparaginase}

1. Biochemical characterization of purified Enzyme: The optimum $\mathrm{pH}$, temperature and determine In vitro half-life for $\mathrm{L}$-asparaginase activity was determined over a $\mathrm{pH}$ range of 2-12 , Temp 20 to $100^{\circ} \mathrm{C}$ and Calculate the activity of L-asparaginase every day respectively. The buffers, potassium phosphate (50 $\mathrm{mM}, \mathrm{pH}$ 5.5-7.5) and Tri-HC1 (50 mM, pH 8.0-10.5) were used for this study. Relative activities were calculated by using the highest absorbance value of L-Asparaginase as $100 \%$, respectively.

2. Effect of metal ions and reagents on L-asparaginase activity: The enzyme activity was determined in the presence of different ions and reagents at concentration previously reported after a 30 -min exposure to each ion and reagents. The relative activity was expressed as the percentage ratio of the activity of the enzyme incubated with the effectors to that of the untreated enzyme.

\section{Results and Discussion}

In this study, an effective L-Asparaginase was purified from Novel Marine Actinomycetes strain using Quantitative Preparative Continuous- Elution SDS PAGE Electrophoresis method. The procedures developed for purification of the enzyme should be as rapid and simplified as possible, providing pure enzyme in high yield. The purified enzyme should have long term stability on storage, maximal activity at a physiological $\mathrm{pH}$, different temp and $\mathrm{Km}$ for substrate below the concentration of the substrate. 
Citation: Senthil Kumar M, Selvam K (2011) Isolation and Purification of High Efficiency L-asparaginase by Quantitative Preparative Continuouselution SDS PAGE Electrophoresis. J Microbial Biochem Technol 3: 073-083. doi:10.4172/1948-5948.1000055

\section{Screening and isolation of actinomycetes}

Screening of bacterial isolates 29 actinomycetes were tested for enzyme production. Only 14 ( $48.27 \%$ )strains were extracellularly significant levels of L-asparaginase producers.A very high percentage of bacteria, $85.71 \%$ and $28.57 \%$ were capable of growing of alkaline $\mathrm{pH}$ 10 and 12 respectively and $7.14 \%$ were also found to be thermo tolerant and consequently would be preferred in industry[26].

Strains producing L-asparaginase were identified by a pink coloured colony on modified M9 agar medium with phenol red as an indicator for detection of L-asparaginase producing colonies [27]. The microbial strain with the pink coloured colony was selected for further studies .The isolated strain (MS1) was characterized by morphological and biochemical tests 16sRNA sequence.

The isolated strain MS1 is Gram Positive, Substrate mycelium olive gray to dark reddish brown and aerial mycelium white to pinkish, especially on Czapek agars. Spores are moderate gray on most media and reddish gray on Czapek agars. Spore chains are in long, open spirals. The spore surface is spiny. Melanin pigments are not produced on Czapek agar.

The Physiological and biochemical properties of strain MS1 also were very similar to those of Streptomyces radiopugnans .Liquefaction of gelatin, Citrate, Urea, Arginine, Lysine, Ornithine decarboxylase, Galactose orthonitrophenol and VP were all Positive but Indole and H2S

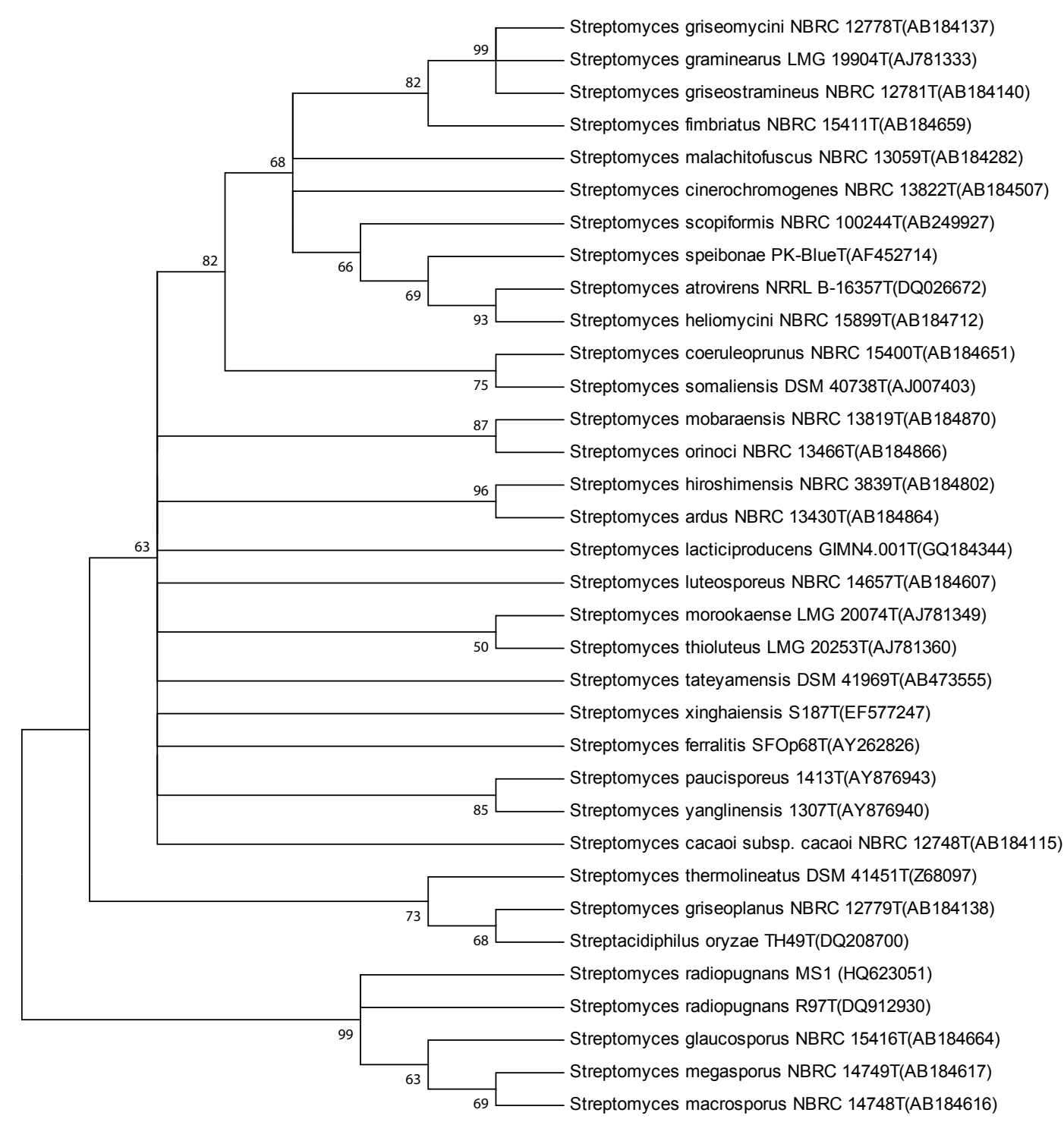

Figure 1: The evolutionary history was inferred using the Neighbor-Joining method (Saitou et al.,1987) . The optimal tree with the sum of branch length $=0.24861088$ is shown. The percentage of replicate trees in which the associated taxa clustered together in the bootstrap test (1000 replicates) are shown next to the branches . The tree is drawn to scale, with branch lengths in the same units as those of the evolutionary distances used to infer the phylogenetic tree. The evolutionary distances were computed using the Maximum Composite Likelihood method [30] and are in the units of the number of base substitutions per site. The analysis involved 34 nucleotide sequences. Codon positions included were $1 s t+2 n d+3 r d+N o n c o d i n g$. All positions containing gaps and missing data were eliminated. There were a total of 888 positions in the final dataset. Evolutionary analyses were conducted in MEGA5 [29] 


\begin{tabular}{|l|l|l|}
\hline Media & $\begin{array}{l}\text { Dry weight of cells } \\
\text { (g/l) }\end{array}$ & L-asparaginase activity $(\mathbf{I U / m l )}$ \\
\hline FM1 & 4.45 & 27.878 \\
\hline FM2 & 6.75 & 45.374 \\
\hline FM3 & 2.17 & 9.569 \\
\hline FM4 & 3.23 & 14.295 \\
\hline FM5 & 3.85 & 19.708 \\
\hline
\end{tabular}

Table 1: Effect of different media on the growth of MS1 Strain and L-asparaginase activity.

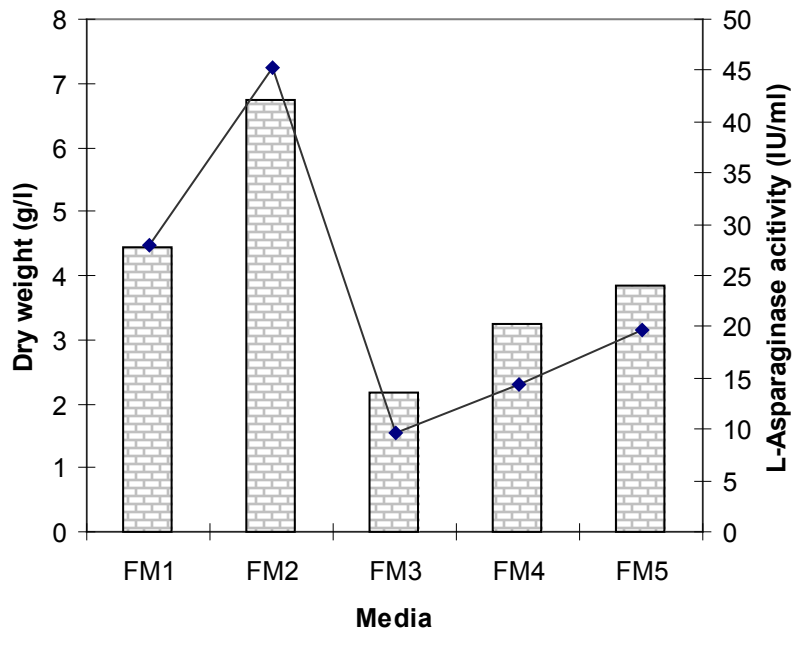

Dry weight of cells $\longrightarrow$ L-asparaginase activity $(\mathrm{IU} / \mathrm{ml})$

Figure 2: Effect of different media on growth and L-Asparaginase activity by Streptomyces radiopugnans $M S 1$.

was negative. Strain was consumed D-Glucose, Inositol, D-Mannitol, D-Fructose, L-Rhamnose, Galactose, Erythritol, Melibiose, Sucrose, Salicin, L-Arabinose and Raffinose but could not utilize D-xylose and Lactose.

The nearly complete 16sRNA sequence of strain MS1 was generated (Genebank accession No. HQ623051).Phylogentic analysis of 16sRNA sequences of the strain and related taxas showed almost complete 16sRNA sequence [28-30] of the strain had 99\% similarity to that of Streptomyces radiopugnans (Genbank accession no. DQ912930) (Figure 1). As a Result, strain MS1 was identified as Streptomyces radiopugnans MS1.

\section{Effect of different media on the growth and asparaginase production}

Different growth media were screened at shake flask level to find out the appropriate media for the optimum growth of the organism and enzyme production (Table 1). Maximum activity (45.37 IU/ml) was observed in the medium $\mathrm{FM}_{2}(\mathrm{~g} / \mathrm{L})$ containing Tapioca effluent $(75 \% \mathrm{v} / \mathrm{v})$,Natural sea water $(25 \% \mathrm{v} / \mathrm{v}) \mathrm{pH}$ 7.2 7.4.. While, minimum activity was recorded in the medium FM3 (Figure 2).

$\mathrm{FM}_{2}$ medium was used as first line production medium, only the $\mathrm{C}$ source and $\mathrm{N}$ source were varied. Different $\mathrm{C}$ and $\mathrm{N}$ sources screened to find the conditions leading to the highest yield and activity at shake flask level. Remarkable L-asparaginase activity $(22.267 \mathrm{IU} / \mathrm{ml})$ was observed in the medium containing carbon source Tapioca as compared to other C sources (Data was not shown).

Although,corn steep liquor $(22.391 \mathrm{IU} / \mathrm{ml})$ showed production of $\mathrm{L}$-asparaginase with maximum activity as compared to other $\mathrm{N}$ sources (Data was not shown).

Out of twenty different amino acids only nine amino acids viz., L-asparagine,L-histidine, L-proline, L-glycine, L-cysteine, Lglutamic acid, L-gutamine, L-theonine and L-serine were acting as $\mathrm{N}$ sources and potentially increased the activity of L-asparaginase when added to the medium as compared to other amino acids. The Lasparaginase activity reached up to maximum $(25.596 \mathrm{IU} / \mathrm{ml})$ when $\mathrm{L}$-asparagine was used as $\mathrm{N}$ source (Data was not shown).

\section{L-Asparaginase production}

The optimum inoculums size for fermentation is $2.5 \%$ and at $2.0 \%$ substrate concentration of corn steep liquor for fermentation. The time period of enzyme production was increased up to $96 \mathrm{~h}$ and thereafter decreased gradually up to $168 \mathrm{hrs}$. The asparaginase production and activity were higher when media was adjusted at $\mathrm{pH} 8.0$ and temperature $30^{\circ} \mathrm{C}$. Indeed there are several approaches to maximize the yield by optimization, but this is only one attempt towards it. By using different novel strategies and combinations of different optimal processes, total yield of catalyst can be improved.

The results of purification steps of L-asparaginase from Streptomyces radiopugnans MS1 are summarized in (Table 2 ).

The partial purification of the L-asparaginase crude extract that was affected by the ammonium sulfate (80\%) precipitation showed that most of the enzyme activity was preserved in the precipitate. The total protein decreased from 4339.82 to $316.985 \mathrm{mg}$ in the ammonium sulfate precipitation step. The specific activity increased to 938.88, 2118.52 and 5035.28IU/mg after the DEAE cellulose column, Sephadex G-200 and Prep cell Model 491 steps, respectively (Figure 3).

The purification of the L-Asparaginase rich fractions of the Prep cell Model 491 is shown in (Figure 4). A sharp distinctive peak of L-asparaginase activity, which fits with only one protein peak, was obtained.

DISC-PAGE of the enzyme preparation from different purification steps showed that the resolved electrophoretic bands were progressively

\begin{tabular}{|l|l|l|l|l|l|l|}
\hline Step & Collected Volume & Total Activity(IU) & Total Protein(mg) & Specific activity(IU ml) & Purification (Fold) & YIELD( \%) \\
\hline Crude `Extract & 450 & 87871.5 & 4339.82 & 20.24 & 100 \\
\hline$\left(\mathrm{NH}_{4}\right)$ 2SO4 & 300 & 72726 & 316.985 & 229.43 & 11.33 \\
\hline DEAE cellulose column & 230 & 63567.4 & 67.705 & 938.88 & 46.37 \\
\hline Sephadex G200 column & 135 & 49889.25 & 23.549 & 2118.52 & 104.63 \\
\hline Prep Cell & 95 & 70927 & 14.086 & 5035.28 & 248.68 \\
\hline
\end{tabular}

Table 2: Summary of steps employed in purification of L-asparaginase from MS1. 


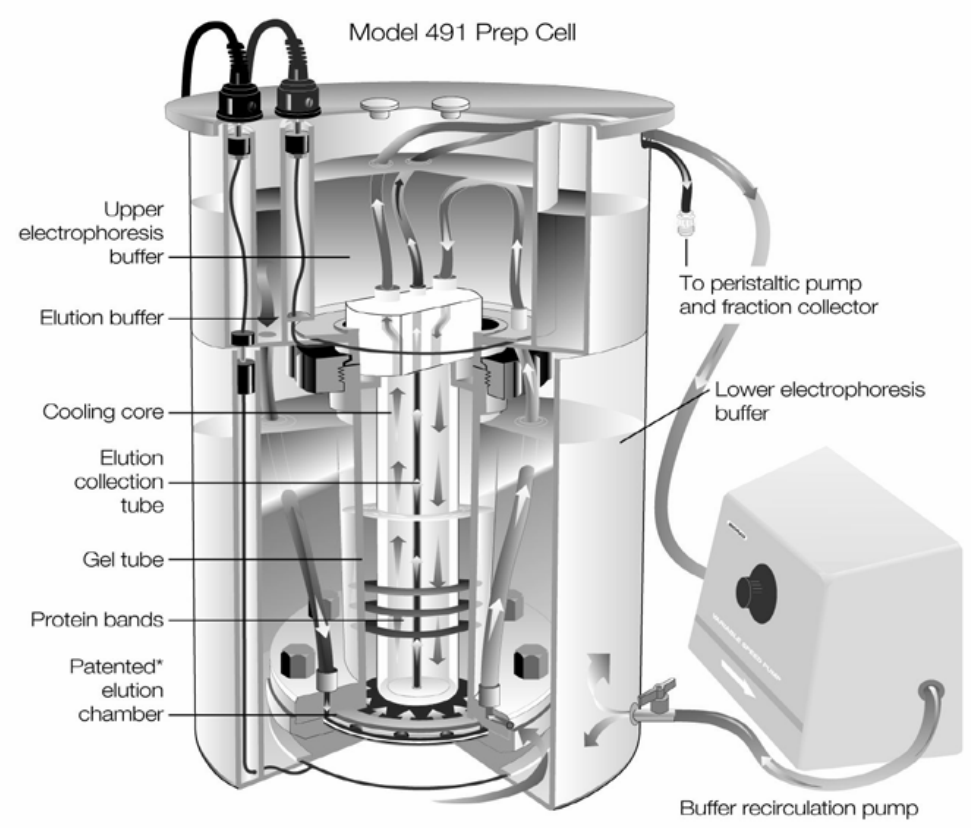

Figure 3: Electrophoresis chamber "Model 491 Prep Cell" for isolating quantitative amounts of L-Asparaginase in complex protein mixtures.

\section{Quantitative Preparative Continuous- Elution SDS Polyacrylamide Gel Electrophoresis elution of L-Asparaginase}

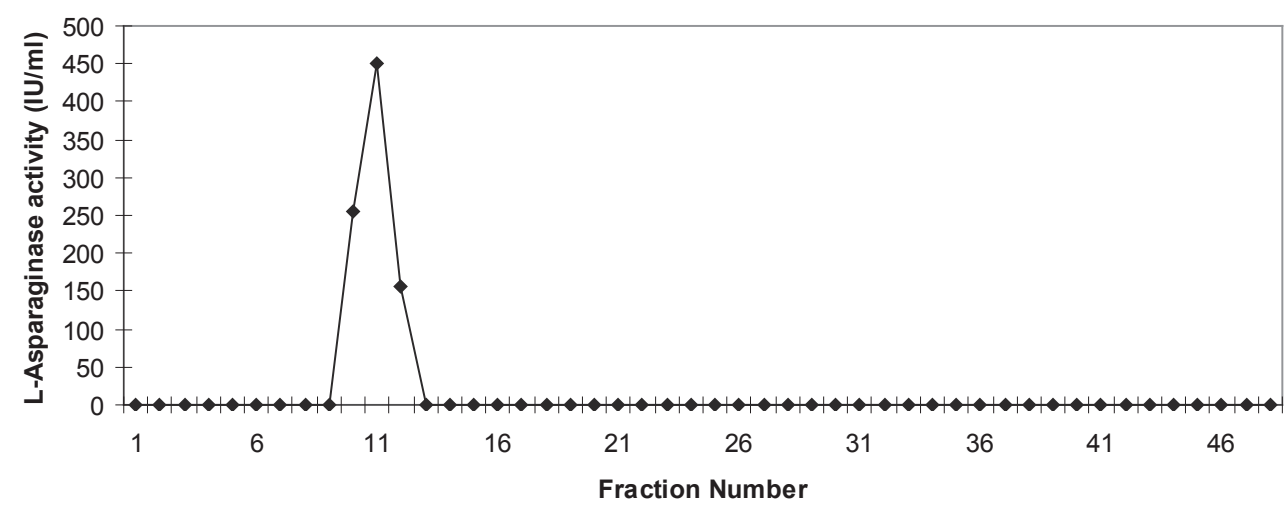

Figure 4: Quantitative Preparative Continuous- Elution SDS Polyacrylamide Gel Electrophoresis elution of L-Asparaginase.

improved from the crude extract to the final step of the Prep cell Model 491. It revealed only one distinctive band that was indicated by the pure preparation of L-asparaginase (Figure 5A).

L-asparaginase was purified to homogeneity after Prep cell Model 491 separation with $80.71 \%$ of yield. The enzyme was purified approximately150-fold with a specific activity of 5035.28IU mg-1 and the molecular weight of the subunits of $\mathrm{L}$-asparaginase was found to be approximately $33.3 \mathrm{kDa}$ by SDS-PAGE analysis (Figure $5 \mathrm{~A}$ ). The purified L-asparaginase has an approximate molecular weight of 133 $\pm 2.5 \mathrm{kDa}$ as assessed by Native PAGE (Figure 5B) and also molecular weight confirmed with MALDI-TOF MS analysis of homotetramer and composed subunits. Molecular mass determination result was similar of both confirmations.

For the most part, this method combines the best features of both gel electrophoresis and column chromatography. On one hand, provided that the appropriate percentage of acrylamide is chosen, this method could replace the commonly used PAGE slab gel method to purify L-Asparaginase of any sequence and length with comparable efficiency and resolution. Alternatively, the capacity of this method approaches that of column chromatography.

Unlike the DEAE cellulose chromatography or Sephadex G-200 chromatography the sample is not destroyed and gel can be used up 
Citation: Senthil Kumar M, Selvam K (2011) Isolation and Purification of High Efficiency L-asparaginase by Quantitative Preparative Continuouselution SDS PAGE Electrophoresis. J Microbial Biochem Technol 3: 073-083. doi:10.4172/1948-5948.1000055
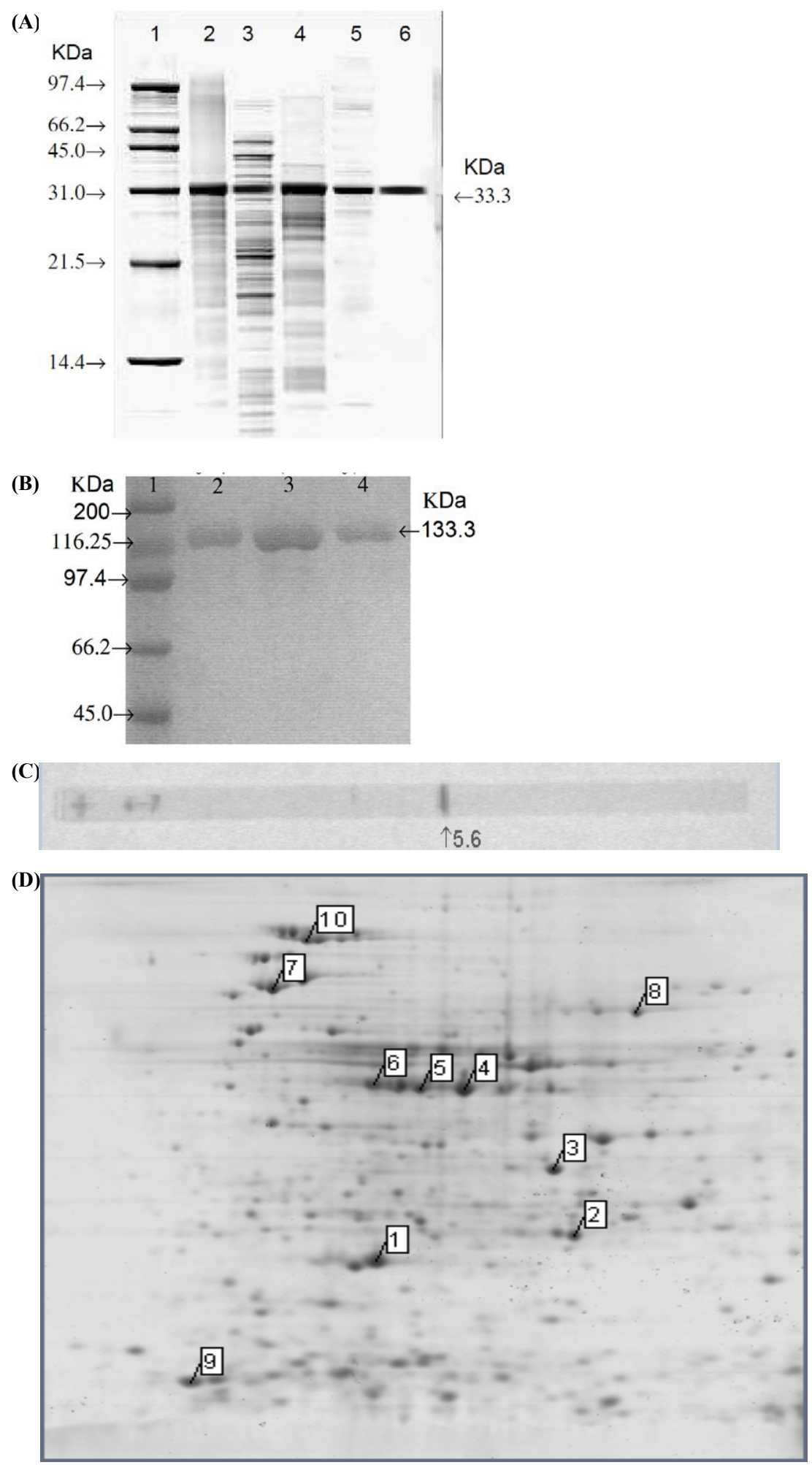

Figure 5: (A): Molecular weight of purified L-asparaginase from Streptomyces radiopugnans MS1 SDS PAGE on gel of stained with Bio-Safe ${ }^{\mathrm{TM}}$ Coomassie stain. 1.Biorad (Protein) low range Protein Marker,2.Crude extract,3.Ammonium sulphate precipitate ,4.DEAE Column chromatography,5.Sephadex G-200,6.Prep cell 491 (B): Molecular weight of purified L-asparaginase from Streptomyces radiopugnans MS1 Native PAGE on gel of stained with Bio-Safe ${ }^{\mathrm{TM}}$ Coomassie stain.1,Biorad (protein)High range marker; 2,3 and 4 purified L-asparaginase.

(C): Bio-Safe ${ }^{\mathrm{TM}}$ Coomassie stained IEF strip containing purified L-asparaginase for determination of pl and evaluated with IEF standards (Bio-Rad, Hercules, CA ).

(D): Representative 2D gels of Streptomyces radiopugnans MS1 protein sample stained with Bio-Safe ${ }^{\mathrm{TM}}$ Coomassie stain.The standards $(2.5 \mu \mathrm{l})$ were run on $7 \mathrm{~cm}$ ReadyStrips in the Mini-PROTEAN II CELL. The polypeptide molecular mass scale compare with 2-D SDS -PAGE Standards(Bio-Rad, Hercules, CA )in kDa is depicted on the $y$-axis while the $x$-axis on the pl range. The proteins were resolved in 4-7 linear $\mathrm{pH}$ gradient. 
Citation: Senthil Kumar M, Selvam K (2011) Isolation and Purification of High Efficiency L-asparaginase by Quantitative Preparative Continuouselution SDS PAGE Electrophoresis. J Microbial Biochem Technol 3: 073-083. doi:10.4172/1948-5948.1000055

to three times without significant loss of resolution, further reducing both time and expense. These features make the Prep Cell method a viable alternative to traditional purification methods, especially for laboratories that need high-resolution purification of large quantities of L-Asparaginase on a routine basis. Given the efficiency and reproducibility of this method, it should greatly assist rapid purification of L-Asparaginase in milligram quantities.

The isoelectric focusing showed that the pI of purified L-asparaginase from Streptomyces radiopugnans MS1 is close to 5.6 (Figure 5C).which is resemble to that of the enzymes from E. coil enzyme ( $\mathrm{pI}=5.0$ ) . different for the Erwinia(8.7). Recently, Abakumova et al. [31] reported that the $\mathrm{pI}$ of L-asparaginase isolated from Yersinia pseudotuberculosis was 5.4.

\section{De novo sequencing}

Ten targeted protein spots (Figure 5D) were identified by MALDITOF-TOF followed by peptide sequencing using PEAKS Studio 5.3 de novo sequencing software. The generalized schematic of the methodology used in the current study to compile a database for Streptomyces sp.The detailed information of the confirmed protein characterization are elaborated with respect to the precursor mass, $\mathrm{m} / \mathrm{z}$ error (ppm), PEAKS score for confidence interval (\%) for the PEAKS de novo generated peptide sequences and their corresponding homology searches. The MS/MS spectrum was analyzed by PEAKS de novo sequencing software to generate "GSLVLLAADGSVDLALGDPAAPVFPR". The peak homology search of this peptide is almost $95 \%$ identical to that of that of N-terminal amino acid sequence of Streptomyces sp. (Figure 6 and 7).

\section{Amino acid composition}

Amino acid contents of the purified Streptomyces radiopugnans MS1 Lasparaginase shown (Table 3).The purified enzyme was rich in Alanine and Leucine. For comparison, the amino acid composition of the enzyme with the compositions of other bacterial asparaginases is shown in (Table 3). The Streptomyces radiopugnans MS1 asparaginase has an amino acid composition generally similar to that of other Streptomyces asparaginases.

\section{Kinetic parameters}

The Km and Vmax of purified L-asparaginase from Streptomyces radiopugnans $M S 1$ were $0.0598 \mathrm{mM}$ and $3.5478 \mathrm{IU} \lg -1$, respectively (Figure 8). This indicates the high affinity of the enzyme to the substrate. L-Asparaginase of different microorganisms has different substrate affinities and probably plays different physiological roles in the enzyme activity. The substrate affinity in terms of $\mathrm{Km}$ is very lower $(0.0598 \mathrm{mM})$ than the reported cytosolic bacterial L-asparaginases [32]. Higher $K m$ values (2.5 mM, $3.5 \mathrm{mM}$ and 0.074) for Lasparaginase from C. glueamicum, E. coli and Vibrio succinogenes, respectively, have been reported [33].

The purified L-asparaginase was active at a $\mathrm{pH}$ range of 5-12. The maximum L-asparaginase activity was obtained at $\mathrm{pH} 6$ and $40^{\circ} \mathrm{C}$, and activity decreased significantly (50\%) when the $\mathrm{pH}$ was decreased to 6.5(Data was not shown). Although maximum activity at a physiological $\mathrm{pH}$ is one of the rudiments of L-asparaginase for antitumor activity, the purified enzyme would useful because $93.7 \%$ of the enzyme activity was retained at $\mathrm{pH} 11$. The enzyme showed stability at $\mathrm{pH}$ 5.0-11.0. The activity of L-asparaginases from Streptomyces radiopugnans MS1. showed alkaline optimum $\mathrm{pH}$ 6-7 which is similar to E. coli exhibited an acidic $\mathrm{pH}$ optimum of 5.0-6.0 [34]. The purified enzyme exhibited

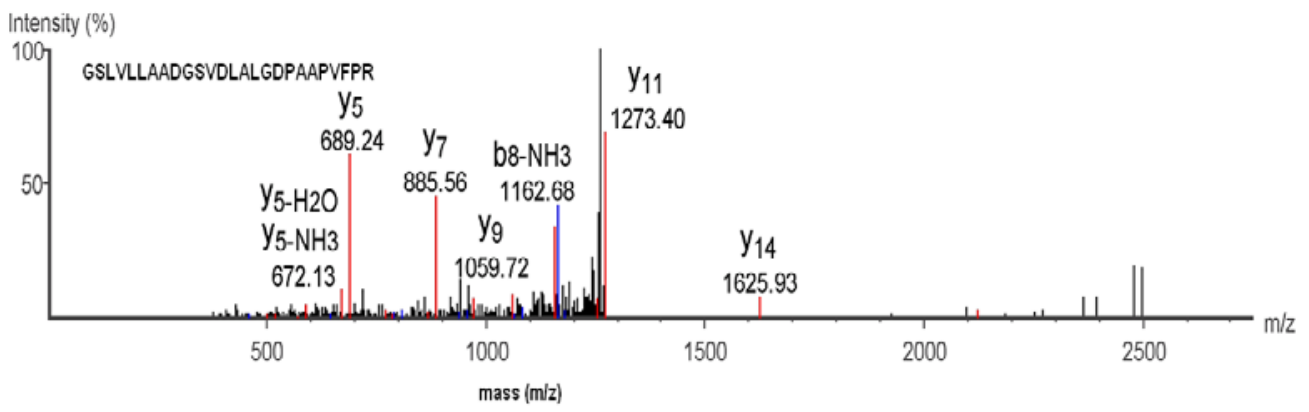

Figure 6: MALDI-MS/MS, spectrum of peptide atm/z2521.36 of L-Asparaginase(PEAKS de novo sequencing software to generate ' GSLVLLAADGSVDLALGDPAAPVFPR '. isolated from Streptomyces radiopugnans MS1 .

PEAKS De Novo sequence : GSLVLLAADGSVDLALGDPAAPVFPR

Rank 1 Protein Description Streptomyces sp. ACTE (NCBI ACCESSION : NZ ADFD01000001) $\mathrm{N}$-terminal L-Asparaginase

1 MTSQNSSASAPLPVLAEVVRSGFTEGHHRGSLVLLAADGSVDLALGDPAAPVFPRSSNKP 60

61 MQAAAILRAGLELSGERLALAAASHSGEDFHLALVRTMLAEHGLTPDDLRTPPDLPLDPV 120 121 EAEAYLAAGRVREPLTMNCSGKHAAMLAVCVRNGWDTATYLDPAHPLQVLVGQMVAEAAG 180 181 EPVAAVGTDGCGAPLMAIGLVGLARAFRAFVTAEPGSAERRVADAMRAHPEYVAGTRRPD 240 241 TWLMREVPGTLSKMGAEAVQAVALADGRALAFKIDDGSTRALGPVLARALELLGVDAPVV 300 301 SRIGRAPLLGGAEEVGRIRAAF 322

Figure 7: The peaks homology search of this peptide resulted in sequence from L-Asparaginase as 'GSLVLLAADGSVDLALGDPAAPVFPR'. 
Citation: Senthil Kumar M, Selvam K (2011) Isolation and Purification of High Efficiency L-asparaginase by Quantitative Preparative Continuouselution SDS PAGE Electrophoresis. J Microbial Biochem Technol 3: 073-083. doi:10.4172/1948-5948.1000055

\begin{tabular}{|c|c|c|c|c|c|c|}
\hline & & $\begin{array}{l}\text { Streptomyces } \\
\text { radiopugnans (M.W } \\
33338.26 \text { ) }\end{array}$ & $\begin{array}{l}\text { Streptomyces pristinaespiralis } \\
\text { ATCC } 25486 \text { (M.W } 33591.41 \text { ) }\end{array}$ & $\begin{array}{l}\text { Streptomyces albus } \\
\text { J1074(M.W 34723.83) }\end{array}$ & $\begin{array}{l}\text { Streptomyces sp. } \\
\text { SPB78 (M.W 33305.04) }\end{array}$ & $\begin{array}{l}\text { Streptomyces sp. AA4 } \\
\text { (M.W 33264.80) }\end{array}$ \\
\hline & Amino Acid & Mol \% & Mol \% & Mol \% & Mol \% & Mol \% \\
\hline Ala & A & 18.01 & 15.74 & 17.96 & 16.82 & 17.14 \\
\hline Cys & C & 0.93 & 0.93 & 1.2 & 1.56 & 0.95 \\
\hline Asp & D & 5.28 & 6.17 & 4.49 & 6.54 & 6.98 \\
\hline Glu & $E$ & 5.9 & 5.25 & 6.29 & 6.23 & 5.4 \\
\hline Phe & $\mathrm{F}$ & 2.17 & 2.16 & 2.4 & 2.18 & 1.9 \\
\hline Gly & G & 9.63 & 10.19 & 9.28 & 9.66 & 7.62 \\
\hline His & $\mathrm{H}$ & 2.48 & 2.78 & 1.8 & 2.18 & 3.17 \\
\hline Ile & 1 & 1.55 & 1.23 & 0.9 & 1.87 & 2.54 \\
\hline Lys & K & 1.24 & 1.85 & 1.2 & 1.25 & 1.9 \\
\hline Leu & L & 12.42 & 11.11 & 11.68 & 11.84 & 11.11 \\
\hline Met & M & 3.11 & 3.4 & 2.99 & 3.12 & 1.9 \\
\hline Asn & $\mathrm{N}$ & 1.55 & 0.93 & 0.9 & 0.62 & 1.9 \\
\hline Pro & $\mathrm{P}$ & 7.14 & 5.56 & 10.78 & 7.79 & 8.25 \\
\hline Gln & Q & 1.24 & 1.85 & 2.1 & 1.56 & 3.17 \\
\hline Arg & $\mathrm{R}$ & 7.76 & 7.41 & 8.08 & 7.17 & 8.25 \\
\hline Ser & $S$ & 4.97 & 7.1 & 4.79 & 5.61 & 4.44 \\
\hline Thr & $\mathrm{T}$ & 4.35 & 4.32 & 3.29 & 4.05 & 4.44 \\
\hline Val & V & 8.7 & 10.49 & 7.78 & 8.1 & 7.3 \\
\hline Trp & W & 0.62 & 0.62 & 0.9 & 0.62 & 0.63 \\
\hline Tyr & $Y$ & 0.93 & 0.93 & 1.2 & 1.25 & 0.95 \\
\hline
\end{tabular}

Table 3: Amino acid composition of bacterial L-asparaginases.

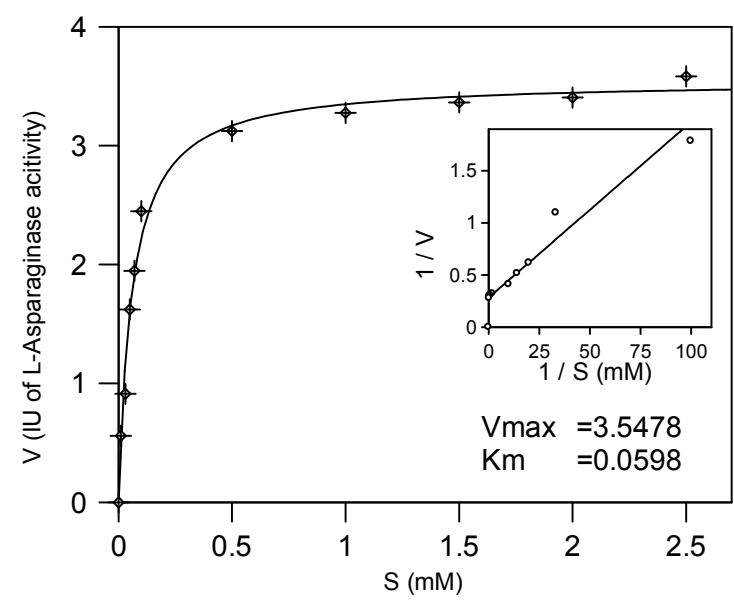

\begin{tabular}{lcc}
\hline Parameter & Value & Std. Error \\
\hline Vmax & 3.5478 & 0.0691 \\
$\mathrm{Km}$ & 0.0598 & 0.0054
\end{tabular}

Figure 8: The kinetic parameters $\mathrm{Km}$ and $\mathrm{Vmax}$ were calculated by nonlinear regression analysis of experimental steady-state data using the computer program GraFit, Erithacus Software. Plot of the reaction velocities (V) vs. substrate concentration (S: $0.00-2.5 \mathrm{mM}$ ) fitted to the MichaelisMenten equation ( $\mathrm{R}$ square $=0.99$ ) and determination of $\mathrm{Km}$ and $\mathrm{Vmax}$ of purified L-asparaginase for L-asparagine by non-linear regression analysis of experimental steady-state data.The corresponding Lineweaver-Burk plot for L-asparaginase catalyzed reaction. maximum activity at $40^{\circ} \mathrm{C}$ and its activity decreased sharply above $90^{\circ} \mathrm{C}$ with a loss of $53 \%$ of its original activity at $80^{\circ} \mathrm{C}$ (Data was not shown). No significant activity was lost when the purified enzyme was preincubated at $40^{\circ} \mathrm{C}$ for $60 \mathrm{~min}$ and beyond this temperature the enzyme became increasingly stable till $80^{\circ} \mathrm{C}$, The result shows that in vitro halflife of the L-Asparaginase was 16 days (Data was not shown).

\section{Influence of metal ions and reagents on 1-asparaginase activity}

L-asparaginase activity was assayed in the presence of various ions and reagents (Table 4). Among the ions tested, significant loss of activity was observed only with $\mathrm{Cu}^{2+}, \mathrm{Cd}^{2+}, \mathrm{Hg}^{2+}, \mathrm{Zn}^{2+}, \mathrm{Ni}^{2+}, \mathrm{Fe}^{3+}$ and $\mathrm{Mg}^{2+}$ but $\mathrm{Na}^{+}, \mathrm{K}^{+}$and EDTA acting as an inducer. The data designate that asparaginase might not be the metalloenzyme. Based on amino acids tested, only L-cysteine and histidine kindle the comparative activity, while others had not apparent result. Inhibition of enzyme activity in presence of $\mathrm{Cu}^{2+}, \mathrm{Cd}^{2+}$ and $\mathrm{Hg}^{2+}$ might be indicative of essential vicinal sulfhydryl groups of the enzyme for productive catalysis. In addition, inspiration of the establishment with reducing agents like reduced glutathione (GSH), 2-mercaptoethanol (2-ME) and dithiothreitol (DTT) and inhibition in the presence of thiol group blocking reagents, specifically, P-chloro mercury benzoate and iodiacetate provided supplementary confirmation for the role of sulfhydryl groups in the catalytic activity of the enzyme. The enzyme entirely lost its activity at 5.0M urea [35] and only 5.0M sodium dodecyl sulfate (SDS).

\section{Conclusion}

From this study, it is clearly indicated that Marine soils can provide a rich source of L-Asparaginase producing actinomycetes. Streptomyces radiopugnans MS1 isolated from Bay of Bengal soil has the ability to produce a significant amount of L-Asparaginase enzyme. 
Citation: Senthil Kumar M, Selvam K (2011) Isolation and Purification of High Efficiency L-asparaginase by Quantitative Preparative Continuouselution SDS PAGE Electrophoresis. J Microbial Biochem Technol 3: 073-083. doi:10.4172/1948-5948.1000055

\begin{tabular}{|c|c|c|}
\hline Addition & Concentration & Realtive Activity (\%) \\
\hline No addtiton & None & 100 \\
\hline $\mathrm{Na}^{+}(\mathrm{NaCl})$ & $10(\mathrm{mM})$ & 122.9 \\
\hline $\mathrm{K}^{+}(\mathrm{KCl})$ & $10(\mathrm{mM})$ & 130.9 \\
\hline $\mathrm{Mg}^{2+}\left(\mathrm{MgCl}_{2}\right)$ & $10(\mathrm{mM})$ & 63.6 \\
\hline $\mathrm{Ca}^{2+}\left(\mathrm{CaCl}_{2}\right)$ & $10(\mathrm{mM})$ & 73 \\
\hline $\mathrm{Mn}^{2+}\left(\mathrm{MnCl}_{2}\right)$ & $10(\mathrm{mM})$ & 75.7 \\
\hline $\mathrm{Zn}^{2+}\left(\mathrm{ZnCl}_{2}\right)$ & $10(\mathrm{mM})$ & 8.4 \\
\hline $\mathrm{Fe}^{3+}\left(\mathrm{FeCl}_{3}\right)$ & $10(\mathrm{mM})$ & 43.4 \\
\hline $\mathrm{Hg}^{2+}\left(\mathrm{HgCl}_{2}\right)$ & $10(\mathrm{mM})$ & 0 \\
\hline $\mathrm{Ni}^{2+}\left(\mathrm{NiCl}_{2}\right)$ & $10(\mathrm{mM})$ & 53.2 \\
\hline $\mathrm{Cu}^{2+}\left(\mathrm{CuCl}_{2}\right)$ & $10(\mathrm{mM})$ & 0 \\
\hline $\mathrm{Cd}^{2+}\left(\mathrm{CdCl}_{2}\right)$ & $10(\mathrm{mM})$ & 0 \\
\hline EDTA & $10(\mathrm{mM})$ & 124.4 \\
\hline L-Cysteine & $25(\mathrm{mM})$ & 143.1 \\
\hline L-Histidine & $25(\mathrm{mM})$ & 118.9 \\
\hline L-Glutamine & $25(\mathrm{mM})$ & 0 \\
\hline Glutathione (reduced) & $5(\mathrm{mM})$ & 133.1 \\
\hline Thiourea & $5(\mathrm{mM})$ & 111 \\
\hline Thioacetic acid & $5(\mathrm{mM})$ & 101.8 \\
\hline Thioacetamide & $5(\mathrm{mM})$ & 104.3 \\
\hline 2-mercaptoethanol & $5(\mathrm{mM})$ & 120.8 \\
\hline Dithiothreitol & $5(\mathrm{mM})$ & 83.9 \\
\hline p-chloro mercury benzoic acid & $5(\mathrm{mM})$ & 0 \\
\hline Iodoacetamide & $5(\mathrm{mM})$ & 0 \\
\hline Sodium dodecyl sulfate & $5(\mathrm{M})$ & 0 \\
\hline Urea & $5(M)$ & 0 \\
\hline $\mathrm{H}_{2} \mathrm{O}_{2}$ & $5(\mathrm{mM})$ & 0 \\
\hline
\end{tabular}

4. Kondrat'Eva NA (1984) Antibiotiki-(Moscow) 29(7):527-531.

5. Gupta N, Mishra S, Basak UC (2007) Occurrence of Streptomyces aurantiacus in mangrove of Bhitarkanika Malaysian. J Microbiol 3: 7-14.

6. Eden OB, Shaw MP, Lilleyman JS, Richards S (1990) Non-randomized study comparing toxicity of Escherichia Coli and Erwinia asparaginase in children with leukaemia. Med Pediat Oncol 18: 497-502.

7. Asselin BL, Lorenson MY, Whitin JC (1993) Comparative pharmacokinetic studies of three asparaginase preparations. J Clin Oncol 11: 1780-1786.

8. Gallagher MP, Marshall RD, Wilson R (1989) Asparaginase as a drug for the treatment of acute lymphoblastic leukemia. Essays Biochem 24: 1-40.

9. Manna S, Sinha A, Sadhukhan R, Chakrabarty SL (1995) Purification, characterization and antitumor activity of L-asparaginase isolated from Pseudomonas stutzeri MB-405. Curr Microbiol 30: 291-298.

10. Christen P, Bramorski A. Revah S, Soccol CR (2000) Characterization of volatile compounds produced by Rhizopus strains grown on agroindustrial solid wastes. Bioresource Technol 71: 211-215.

11. Gulati R, Saxena R.K, Gupta R (1997) A rapid screening for L-asparaginase producing microorganisms. Lett Appl Microbiolo 24: 23-26.

12. Liang Ye, Qingfeng Zhou, Chunhui Liu, Xuegang Luo, Guangshui Na, et al. (2009) identification and fermentation optimization of a marine-derived streptomyces griseorubens with anti-tumor activity. Indian J Mar Sci 38: 14-21.

13. Kuster E, Williams ST (1964) Selection of media for isolation of Streptomyces. Nature 202: 928-929. DOI 10.1038/202928a0.Http://adsabs.harvard.edu/l abs/1964 Nature.202.928K

14. Edwards U Rogall T, Blocker H, Emde M, Bottger EC (1989) Isolation and direct complete nucleotide determination of entire genes, Characterization of a gene coding for $16 S$ ribosomal RNA. Nucleic Acids Res 17: 7843-7853.

15. Embley MT, Stackebrandt E (1994) The molecular phylogeny and systematics of actinomycetes. Annu Rev Microbiol Felsenstein J 48: 257-289.

16. Mashburn LT, Wriston Jr JC (1964) Tumor inhibitory effect of L-asparaginase from Escherichia coli. Arch Biochem Biophys 105: 450-452.

17. Bradford MA (1976) A rapid and sensitive method for the quantitation of microgram quantities of protein utilizing the principle of protein-dye binding Anal Biochem 72: 248-254.

18. Gallagher SR (1999) One-dimensional electrophoresis using nondenaturing conditions. Curr Protoc Mol Biol 47: 10.2B.1-10.2B.11.

19. Laemmli UK (1970) Cleavage of structural proteins during the assembly of the head of bacteriophage T4. Nature 227: 680-685.

20. Deutscher MP(1990) Guide to protein purification. Methods Enzymol 182: 430431.

21. Gharahdaghi F, Weinberg CR, Meagher DA, Imai BS, Mische SM (1999) A method for the removal of silver ions to enhance sensitivity. Electrophoresis 20 : 601-605.

22. Tannu NS, Wu J, Rao VK, Gadgil HS, Pabst MJ, et al (2004) Paraffin-waxcoated plates as matrix-assisted laser desorption / ionization sample support for high-throughput identification of proteins by peptide mass fingerprinting. Anal Biochem 327: 222-232.

23. Ma B, Zhang K, Hendrie C, Liang C, Li M, et al. (2003) PEAKS: powerful software for peptide de novo sequencing by tandem mass spectrometry. Rapid Commun Mass Spectrom 17: 2337-2342.

24. Patterson SD, Aebersold R (1995) Mass spectrometric approaches for the identification of gel-separated proteins. Electrophoresis 16: 1791-1814.

25. Spekman DH, Moore S, Steins W (1958) Chromatography of amino acids on sulphonated polystyrene resins. Anal Chem 30: 1185-1190.

26. Alhar HO, Lewis DA (1985) Anti-tumor effect of L-asparaginase. Biochem Pharmacol 34: 275-83

27. Prakasham RS, Hymavathi M, Subba Rao Ch, Arepalli SK,Venkateswara Rao $\mathrm{J}$, et al. (2010) Evaluation of antineoplastic activity of extracellular asparaginase produced by isolated Bacillus circulans.Appl. Biochem. Biotechnol 160: 72-80. 
Citation: Senthil Kumar M, Selvam K (2011) Isolation and Purification of High Efficiency L-asparaginase by Quantitative Preparative Continuouselution SDS PAGE Electrophoresis. J Microbial Biochem Technol 3: 073-083. doi:10.4172/1948-5948.1000055

28. Saitou N, Nei M (1987) The neighbor-joining method: A new method for reconstructing phylogenetic trees. Molecular Biology and Evolution 4: 406-425.

29. Tamura K, Dudley J, Nei M, Kumar S (2007) MEGA4: Molecular Evolutionary Genetics Analysis (MEGA) software version 4.0. Molecular Biology and Evolution 24: 1596-1599.

30. Tamura K, Nei M, Kumar S (2004) Proceedings of the National Academy of Sciences (USA) 101: 11030-11035.

31. Abakumova O Yu, Podobed OV, Borisova AA, Sidoruk KV, Alexandrova SS, et al. (2009) Antitumor activity of L-asparaginase from Yersinia pseudotuberculosis. Biochem (Mosc) Suppl B Biomed 3: 198-201.
32. Kumar S, Pakshirajan K, Venkata Dasu V (2010) Localization and production of novel L-asparaginase from Pectobacterium carotovorum MTCC 1428. Process Biochem 45: 223-229.

33. Willis RC, Woolfolk R (1974) Asparagine utilization in E. coli. J Bacteriol 118 231-241.

34. Muller HJ, Boos J (1998) Use of L-asparaginase in childhood ALL. Crit Rev Oncol / Hematol 28: 97-113.

35. Papageorgiou AC, Posypanova GA, Andersson CS, Sokolov NN, and Krasotkina J (2008) Structural and functional insights into Erwinia carotovora L-asparaginase. FEBS Journal 275: 4306-4316. 